\title{
Impact of Corporate Governance on the Performance of Selected Banks in Nigeria
}

\author{
Adedeji Elijah Adeyinka \\ Federal University of Technology, Akure, Ondo State \\ Ajulo Olajide Benjamin \\ Ladoke Akintola University of Technology, Ogbomoso
}

\begin{abstract}
The impact of corporate governance on the performance of selected banks in Nigeria has become a widereaching truism that the quality of corporate governance makes a significant difference to and has a chief effect on the performance of banks. Effective corporate governance requires a clear understanding of the respective role of the board and of senior management and their relationships with others in the corporate structure. This study aim to examine the relationship that exists between corporate governance and banks performance of selected commercial banks in Nigeria. Using regression analysis of 5 years ranging from $2014-2018$. The stock performance being the response variable was captured by Market price per share (MPS) while the explanatory variables included Board Size (BS), Corporate Governance Disclosure Index (CGDI), Non-Executive Director (NED) and Number of Female Director (NUM) are the regressors used in achieving this objective. Descriptive analysis was used to ascertain the mean (1.64141; MPS, 2.658831; BS, 2.145323; NED, 1.127043; NUM 0.933143; CGDI) median, Maximum, Minimum. Correlation was carried out and a positive and strong relationship were generated.Post estimation diagnostic test of Hausman test and redundant fixed effect test were adopted in selecting the most appropriate model to capture the impact of corporate governance characteristics on stock performance of banks. The test indicated that random effect is not an appropriate model and non-normality of the variables will not encourage the use of ordinary effect, therefore, in estimating the parsimonious model of the variable, fixed effect will be an appropriate assumption. $86.78 \%$ of the stock performance of banks was accounted for by the explanatory variables. The work suggests that efforts should be made to improve corporate governance focus on the stock performance of deposit money banks since the stock performance is a measure of the wealth of shareholders. Also, the Central bank of Nigeria and other relevant authorities should also try to ensure that steps are taken for mandatory and absolute compliance with the code of corporate governance. Also, an effective legal framework should be developed that specifies the rights and obligations of a bank, its directors, shareholders, specific disclosure requirements and provide for effective enforcement of the law.
\end{abstract}

Keywords: Performance, Corporate Governance, Banks, Measure and Shareholders.

DOI: $10.7176 /$ RJFA/11-16-12

Publication date:August $31^{\text {st }} 2020$

\section{INTRODUCTION}

It has become a wide-reaching truism that the quality of corporate governance makes a significant difference to and has a chief effect on the performance of banks. Corporate governance, in simple term, refers to the extent to which companies are run in a manner that is fair, open and acceptable. Thus, effective corporate governance practice combines transparency, openness, accurate reporting and compliance with statutory regulations among others. Antecedents and experiences indicate there is a noteworthy relationship between good corporate governance in banks and their financial performance; invariably one of the sources of instability and unpredictability in the banking sector is lack or inadequate practice of corporate governance. Wherever a power is achieved, either directly or through delegation, to direct, control and regulate activities that affect people, there is need for good, noble and worthy exercise of such power. For corporate entities, particularly public liability companies, the exercise of power over the enterprise's direction, the supervision and control of executive actions, concern for the effects of the enterprise's operations on other parties and especially the environment, the acceptance of a fiduciary duty to be accountable for such, constitute the ideal corporate governance practice.

The Consolidation of the Nigeria Banking Industry makes the institution of corporate governance a prerequisite in the industry. Presently, twenty-two publicly quoted commercial banks exists, hence, the need for corporate governance to take the centre stage in the control and supervision of these banks. Hence, effective corporate governance requires a clear understanding of the respective role of the board and of senior management and their relationships with others in the corporate structure. The relationships of the board of directors with shareholders should be characterized by openness; their relationships with employees should be characterized by fairness; their relationships with the communities in which they operate should be characterized by good and responsible citizenship, and their relationships with government should be characterized by commitment to compliance and good corporate citizenship (Anya, 2003). 
Banks, like many other commercial establishments are expected to generate profit through effective and efficient utilization of resources (inputs) to create sound asset portfolio (output) and ensure the maximisation of shareholders' wealth. Banks make profit from the spread between interest charged on deposit and loan interest rate. These differentials ought to compensate adequately for the investors contribution and the service provider as well, if corporate governance has to be used as a yard stick in determining financial performance. Banks financial performance therefore, could be seen in terms of the absolute profits, rate of return, earnings per share, market price per share, the quality of asset portfolio, and the level of liquidity. Banks' financial performance however is not determined by inputs of managers alone but is also dependent on the environment within which the bank operates.

\section{STATEMENT OF THE PROBLEM}

Nigerian Banks are faced with myriad of problems despite the mandatory action of banks consolidation pronounced by Central Bank of Nigeria $(\mathrm{CBN})$ in 2005 so as to make banks more effective and strengthen their performance. However, several banks collapsing as a result of weak systems of corporate governance and internal control system have highlighted the need to improve and reform corporate governance at an international level. (Onakoya,Ofoegbu and Fasanya 2011). The multifaceted corporate governance problems in the Nigerian banking sector include: weak internal control system, non-compliance with laid down internal control and operational procedure, ignorance of and non-compliance with rules, laws and regulations guiding banking business; passive shareholders, disagreement between board and management giving rise to board squabbles, ineffective board oversight function, fraudulent and self-serving practices among members of the board, management and staff, over bearing influence of chairman or Chief Executive Officer (CEO), non-challant attitude of owners, poor risk management practices, resulting in large quantity of non-performing loans including insider-related credit; sit tight directors-even where such directors fail to make meaningful contribution to the growth and development of the banks; succumbing to pressure from other stakeholders like shareholders appetite for high dividend and returns and depositors quest for high interest on deposits, technical incompetence, poor leadership and administrative inability, inability to plan and respond to changing business circumstance as at when due and ineffective management information system (Yauri, Muhammed and Kaoje, 2012).

The experiences of advanced countries have demonstrated a positive marriage of convenience between well-coordinated wealth management and economic development. Lack of framework to manage wealth continues to plague and plunge less developed counties, like Nigeria into the vicious circle of poverty. Nigeria has a lot of resources being the seventh largest oil producer in the world but lack the ability to manage wealth by effectively developing and encouraging indigenous and foreign investment. This inability has a direct relationship with the need for efficient corporate governance in Nigeria for sustainable development. The lack of effective corporate governance in Nigeria has worked to the disadvantage of shareholders and created a class of stakeholder who has lost interest in the system. The corporate governance culture in Nigeria have persistently failed to be responsible to the stakeholders and has no deep rooted mechanisms to a balance among the major players (board of directors, shareholders and management) in the system or economy. However, corporate governance improves management oversight and increases disclosure and quality of reported financial information (Hermalin, 2005) and reduces the information asymmetry between managers and capital providers (Dogan \& Smyth, 2002).

Several researches have been undertaken in this area and each researcher gave a different view and results. Emeka and Alem (2016) studied the effects of corporate governance on bank's financial performance in Nigeria for period of 2004-2013. Other research works focused on the corporate governance and bank's financial performance in Nigeria and /or in other countries include, Dzingai and Fakoya (2017), Nguyen and Tran (2017), Muhammed (2013), Yauri, Muhammed and Kaoje (2012), Onakoya, Ofoegbu and Fasanya (2011), Uwuigbe (2011). However, the review of previous empirical literature revealed a lack of established significant influence of corporate governance on return on assets over the period of 2013- 2017 that is, five years' financial summary in the research findings of past researchers which indicates the existence of a research gap. Therefore, this research study seeks to close this gap by providing a detailed analysis of the relationship that exists between corporate governance and banks performance of selected commercial banks in Nigeria.

\section{RESEARCH QUESTIONS}

(i) What is the level of corporate governance on performance of selected commercial banks in Nigeria?

(ii) What is the relationship between the level of corporate governance disclosure and the performance of selected commercial banks in Nigeria?

(iii) What is the effect of corporate governance characteristics on performance of selected commercial banks in Nigeria? 


\section{OBJECTIVES OF THE STUDY}

The general objective of this study is to analyse the impact of corporate governance on banks performance in Nigeria while the specific objectives of this study are to:

(i) determine the level of corporate governance on selected commercial banks in Nigeria over the period of study. ascertain the relationship between the level of corporate governance disclosure and the performance of selected commercial banks in Nigeria.

(iii) analyse the effect of corporate governance characteristics on performance of selected commercial banks in Nigeria.

\section{HYPOTHESES OF THE STUDY}

$\mathrm{H} 0$ : Corporate governance has no impact on banks performance in Nigeria

H1: Corporate governance has an impact on banks performance in Nigeria.

\section{LITERATURE REVIEW}

There are many ways of defining corporate governance, ranging from narrow definitions that focus on companies and their shareholders, to broader definitions that incorporate the accountability of companies to many other groups of people, or stakeholders'. Some of these include:

The Organisation for Economic Co-operation and Development (OECD) in 1999 defined corporate governance as the system by which business corporations are directed and controlled. The corporate governance structure specifies the distribution of rights and responsibilities among different participants in the corporation, such as, the board, managers, shareholders and other stakeholders, and spells out the rules and procedures for making decisions on corporate affairs. By doing this, it also provides the structure through which the company objectives are set, and the means of attaining those objectives and monitoring performance." Oman (2001) defined corporate governance refers to the private and public institutions that include laws, regulations and the business practices which govern the relationship between the corporate managers and the stakeholders.

The Organization for Economic Cooperation and Development provides another perspective by stating that "corporate governance is the system by which business corporations are directed and controlled. The corporate governance structure specifies the distribution of rights and responsibilities among different participants in the corporation, such as the Board, managers, shareholders and other stakeholders, and spells out the rules and procedure for making decisions on corporate affairs.

\section{HISTORICAL OVERVIEW OF CORPORATE GOVERNANCE}

The premise of the argument of corporate governance, as seen by both academics as well as other independent researchers, can be traced back to the pioneering work of Berle and Means (1932). They observed that the modern corporations having acquired a very large size could create the possibility of separation of control over a firm from its direct ownership. Berle and Means ${ }^{\text {ee }}$ observation of the departure of the owners from the actual control of the corporations led to a renewed emphasis on the behavioural dimension of the theory of the firm.

Governance is a word with a pedigree that dates back to Chaucer. In his days, it carries with it the connotation "wise and responsible", which is appropriate. It means either the action or the method of governing and it is in the latter sense that it is used with reference to companies. Its Latin root, "gubernare" means to steer and a quotation which is worth keeping in mind in this context is: "He that governs sit s quietly at the stern and scarce is seen to stir" (Cadbury, 1992).

\section{PRINCIPLES OF GOOD CORPORATE GOVERNANCE}

Pandey (2005) opines that good corporate governance requires companies to adopt practices and policies which compromise performance, accountability, effective management control by the board of directors, constitution of board committee as part of professionally qualified, non-executive and independent directors on the board, the adequate timely disclosure of information and the prompt discharge of statutory duties. Chris (2006) sees key elements of good corporate governance principles as also include honesty, trust and integrity, openness, performance orientation, responsibility and accountability, mutual respect and commitment to the organisation. Directors and management develop a model of governance that aligns the values of the corporate participants and then evaluate this model periodically for its effectiveness. In particular, senior executives should conduct themselves honestly and ethically especially concerning actual or apparent conflict of interest and disclosure in financial report.

The Organization for Economic Cooperation and Development (OECD) put forward a set of international principles of corporate governance. These principles were developed both in response to growing recognition of the importance of governance to enterprise performance. The OECD principles are organised under five headings, namely: the right of shareholders, the equitable treatment of shareholders, the role of stakeholders, 
disclosure \& transparency, and the responsibility of the board.

The rights of shareholders

This principle deals with the rights of shareholders. It concerns the protection of shareholders rights and the ability of shareholders to influence the behaviour of the corporation. The basic shareholders' rights include the right to: secure methods of ownership registration; convey or transfer shares; obtain relevant information on the corporation on the timely and regular basis; participate and vote in general shareholder meetings; elect members of the board; and share in profits of the corporation. Fredrick (1999) notes that while these rights are important to good governance, it must be noted that extensive rights in and of themselves are not equivalent to good governance.

\section{Equitable treatment of shareholders}

This principle emphasizes that all shareholders, including foreign shareholders, should be treated fairly by controlling shareholders, board and management. This principle calls for transparency with respect to the distribution of voting rights and the ways in which voting rights are exercised. The high points of the principles include: all shareholders of the same class should be treated equally. Insider trading and abusive self-dealing should be prohibited. Members of the board and management should be required to disclose any material interests in transactions or matters affecting the corporation.

\section{The role of stakeholders}

A good corporate governance framework should recognise the rights stakeholders have, as established by law, such a framework should encourage active cooperation between corporations and stakeholders in creating wealth, jobs and the sustainability of a sound enterprise. To achieve this, corporate governance should ensure that; the rights of stakeholders are protected by law, the rights of the shareholders are respected; stakeholders have the opportunity to redress any violation of their rights, permit performance enhancing mechanism for stakeholder's participation, provides stakeholders with access to all relevant information to enable them participate actively in the governance process.

\section{CONCEPTS OF GOOD GOVERNANCE}

According to the Institute of Chartered Accountants of Nigeria (ICAN), there are several concepts of corporate governance. In companies, these concepts should be evident in the relationship between the shareholders and the board of directors. Some of these concepts should also apply to the company's dealings with its employees, customers, suppliers and the general public. These concepts are described briefly to see the importance of the applicability of these concepts. In particular, how the absence of these concepts might affect the relationship between the board of directors and the shareholders.

\section{Fairness}

In corporate governance, fairness refers to the principle that all shareholders should receive fair treatment from the directors. At a basic level, it means that all the equity shareholders in a company should be entitled to equal treatment, such as one vote per share at general meetings of the company and the right to same dividend per share. In UK for example, the concept of fair treatment for shareholders is supported by the law (which provides some protection for minority shareholders against unjust treatment by the directors or majority shareholders). However, in some countries, the law provides little or no protection for minority shareholders. For example, in a takeover bid for a company, the law might permit a higher price to be offered to large shareholders than the price offered to small shareholders.

\section{Openness/Transparency}

Openness or transparency means „not hiding anythinge". Intentions should be clear, and information should not be withheld from individuals who ought to have a right to receive it. Transparency means clarity. In corporate governance, it should refer not only to the ability of the shareholders to see what the directors are trying to achieve. It also refers to the ease with which an „outsiderse ${ }^{c e}$ such as a potential investor or an employee can make a meaningful analysis of the company and its intentions. Transparency therefore means providing information about what the company has done, what it intends to do in the future and what risks it faces. In public sector organisations and government, openness means telling the public and not making decisions ,behind closed doorsee.

In listed companies (such as banks) openness includes matters such as:

- Requiring major shareholders to declare the size of their shareholding in the company.

- Requiring the board of directors to announce to the stock market information about any major new developments in the company's affairs, so that all shareholders and other investors are kept informed.

\section{Responsibility and Accountability}

The directors of a company are given most of the powers for running the company. Many of these powers are delegated to executive managers, but the directors remain responsible for the way in which those powers are used. An important role of the board of directors is to monitor the decisions of executive management and to satisfy themselves that the decisions taken by management are in the best interests of the company and its 
shareholders. The board of directors should also retain the responsibility for certain key decisions, such as setting strategic objectives for their company and approving major capital investments. A board of directors should not ignore their responsibilities by delegating too many powers to executive management, and letting the management team ,get the job ${ }^{\text {ee }}$; the board should accept its responsibilities.

With responsibility, there should also be accountability. In a company, the board of directors should be accountable to the shareholders. Shareholders should also be able to consider reports from the directors about what they have done, and how the company has performed under their stewardship, and give their approval or show disapproval. Some of the ways in which the board are accountable are as follows:

(i) Presenting the annual reports and accounts to the shareholders, for the shareholders to consider and discuss with the board. This happens at the annual general meeting of the company.

(ii) If shareholders do not approve of a director, they are able to remove him from office. Individual directors may be required to submit themselves for re-election by shareholders at regular intervals. In the UK for example, it is common practice for directors to retire every three years and stand for re-election at the Company's annual general meeting.

\section{CORPORATE GOVERNANCE MECHANISMS}

One consequence of the separation of ownership from management is that the day to day decision-making power (that is, the power to make decision over the use of the capital supplied by the shareholders) rests with persons other than the shareholders themselves. The separation of ownership and control has given rise to an agency problem whereby there is the tendency for management to operate the firm in their own interests, rather than those of shareholders (Jensen and Meckling, 1976; Fama and Jensen, 1983). This creates opportunities for managers to build illegitimate empires and, in the extreme, outright expropriation. Various suggestions have been made in the literature as to how the problem can be reduced (Jensen and Meckling, 1976; Shleifer and Vishny, 1997 and Hermalin and Weisbach, 1998). Some of the mechanisms (based on Shleifer and Vishny, 1997), and their impediments to monitor and shape banks ${ }^{\text {ee }}$ behaviour are discussed below:

\section{Shareholders}

Shareholders play a key role in the provision of corporate governance. Small or diffuse shareholders exert corporate governance by directly voting on critical issues, such as mergers, liquidation, and fundamental changes in business strategy and indirectly sby electing the boards of directors to represent their interests and oversee the myriad of managerial decisions. Incentive contracts are a common mechanism for aligning the interests of managers with those of shareholders. The Board of directors may negotiate managerial compensation with a view to achieving particular results. Thus small shareholders may exert corporate governance directly through their voting rights and indirectly through the board of directors elected by them. However, a variety of factors could prevent small shareholders from effectively exerting corporate control. There are large information asymmetries between managers and small shareholders as managers have enormous discretion over the flow of information. Also, small shareholders often lack the expertise to monitor managers accompanied by each investor's small stake, which could induce a free-rider problem.

Large (concentrated) ownership is another corporate governance mechanism for preventing managers from deviating too far from the interests of the owners. Large investors have to acquire information and monitor managers. They can also elect their representatives to the board of directors and thwart managerial control of the board. Large and well-informed shareholders could be more effective at exercising their voting rights than an ownership structure dominated by small, comparatively uninformed investors. Also, they could effectively negotiate managerial incentive contracts that align owner and manager interests than poorly informed small shareholders whose representatives, the board of directors, can be manipulated by the management. However, concentrated ownership raises some corporate governance problems.

Large investors could exploit business relationships with other firms they own which could profit them at the expense of the bank. In general, large shareholders could maximize the private benefits of control at the expense of small investors.

\section{Debt Holders}

Debt purchasers provide finance in return for a promised stream of payments and a variety of other covenants relating to corporate behaviour, such as the value and risk of corporate assets. If the corporation violates these covenants or default on the payments, debt holders typically could obtain the rights to repossess collateral, throw the corporation into bankruptcy proceedings, vote in the decision to reorganize, and remove managers. However, there could be barriers to diffuse debt holders to effectively exert corporate governance as envisaged. Small debt holders may be unable to monitor complex organization and could face the free-rider incentives, as small equity holders. Also, the effective exertion of corporate control with diffuse debts depends largely on the efficiency of the legal and bankruptcy systems. Large debt holders, like large equity holders, could ameliorate some of the information and contract enforcement problems associated with diffuse debt. Due to their large investment, they are more likely to have the ability and the incentives to exert control over the firm by monitoring managers. 
Large creditors obtain various control rights in the case of default or violation of covenants. In terms of cash flow, they can renegotiate the terms of the loans, which may avoid inefficient bankruptcies. The effectiveness of large creditors however, relies importantly on effective and efficient legal and bankruptcy systems. If the legal system does not efficiently identify the violation of contracts and provide the means to bankrupt and reorganize firms, then creditors could lose a crucial mechanism for exerting corporate governance. Also, large creditors, like large shareholders, may attempt to shift the activities of the bank to reflect their own preferences. Large creditors for example, as noted by Myers (1997) may induce the company to forego good investments and take on too little risk because the creditor bears some of the cost but will not share the benefits.

According to Oman (2001), corporate governance mechanisms including accounting and auditing standards are designed to monitor managers and improve corporate transparency. Furthermore, a number of corporate governance mechanisms have been identified analytically and empirically. These, according to Agrawal and Knoeber (1996), may be broadly classified as internal and external mechanisms as summarized below:

\section{External corporate governance mechanisms}

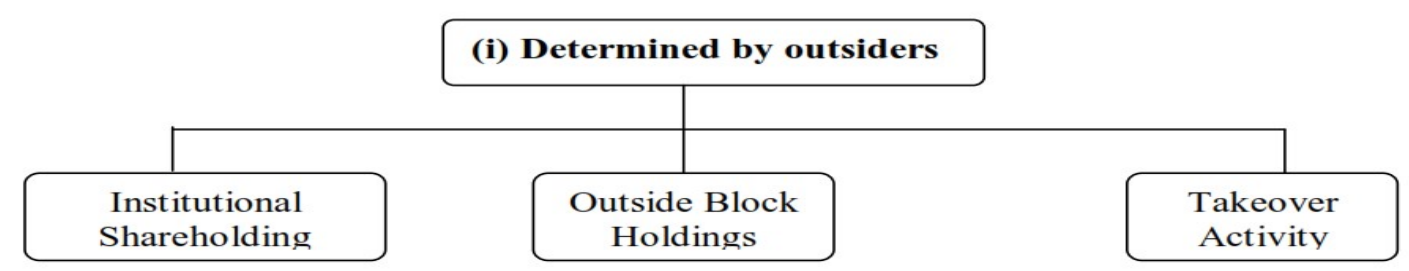

Source: Adapted from Agrawal and Kneober (1996)

Internal Corporate governance mechanisms

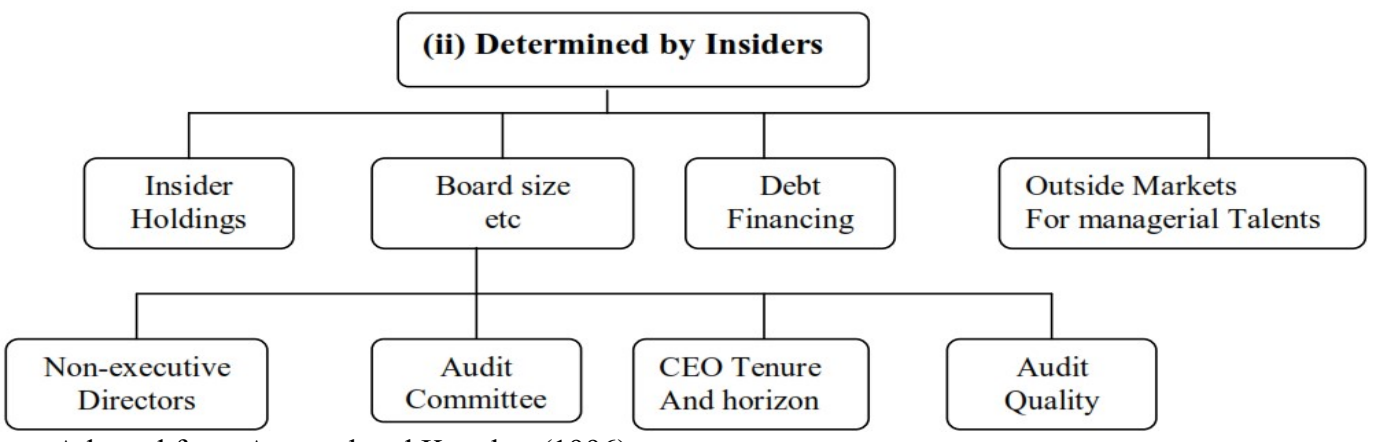

Source: Adapted from Agrawal and Kneober (1996)

Davis, Schoorman and Donaldson (1997) suggest that governance mechanisms "protect shareholders" interest, minimise agency costs and ensure agent-principal interest alignment". They further opined that agency theory assumptions are based on delegation and control, where controls "minimise the potential abuse of the delegation". This control function is primarily exercised by the board of directors.

\section{Agency Theories}

Much of the research into corporate governance derives from agency theory. Since the early work of Berle and Means in 1932, corporate governance has focused upon the separation of ownership and pedals which results in principal-agent problems arising from the dispersed ownership in the modern corporation. They regarded corporate governance as a mechanism where a board of directors is a crucial monitoring device to minimize the problems brought about by the principal-agent relationship. In this context, agents are the managers, principals are the owners and the boards of directors' act as the monitoring mechanism (Mallin, 2004). Moreover, literature on corporate governance attributes two factors to agency theory. The first factor is that corporations are reduced to two participants, managers and shareholders whose interests are assumed to be both clear and consistent. A second notion is that humans are self-interested and disinclined to sacrifice their personal interests for the interests of the others (Daily, Dalton \& Cannella, 2003). The seminal papers of Alchian and Demstez (1972) and Jensen and Meckling (1976), describe the firm as a nexus of contracts among individual factors of production resulting in the emergence of the agency theory. The firm is not an individual but a legal fiction, where conflicting objectives of individuals are brought into equilibrium within a framework of contractual relationships. These contractual relationships are not only with employees, but with suppliers, customers and creditors (Jensen \& Meckling, 1976). The intention of these contracts is that all the parties acting in their selfinterest are motivated to maximize the value of the organization, reducing the agency costs and adopting accounting methods that most efficiently reflect their own performance (Deegan, 2004).

However, the agency problem depends on the ownership characteristics of each country. In Countries where 
ownership structures are dispersed, if the investors disagree with the management or are disappointed with the performance of the company, they use the exit options, which will be signalled through reduction in share prices.

Whereas countries with concentrated ownership structures and large dominant shareholders, tend to control the managers and expropriate minority shareholders in order to gain private control benefits (Spanos, 2005).

Therefore, according to the view of the agency theorists, an efficient market is considered a solution to mitigate the agency problem, which includes an efficient market for corporate control, management labour and corporate information (Clarke, 2004). According to Johanson and Ostergen (2010) even though agency theory provides a valuable insight into corporate governance, its ee applies to countries in the Anglo-Saxon model of governance as in Malaysia. Various governance mechanisms have been discussed by agency theorists in relation to protecting the shareholder interests, minimizing agency costs and ensure alignment of the agent-principal relationship. Among the mechanisms that have received substantial attention, and are within the scope of this study, are the governance structures (Davis, Schoorman \& Donaldson, 1997).

Stakeholder Theory

This theory centres on the issues concerning the stakeholders in an institution. It stipulates that a corporate entity invariably seeks to provide a balance between the interests of its diverse stakeholders in order to ensure that each interest constituency receives some degree of satisfaction (Abrams, 1951). However, there is an argument that the theory is narrow (Coleman, 2008) because it identifies the shareholders as the only interest group of a corporate entity. However, the stakeholder theory is better in explaining the role of corporate governance than the agency theory by highlighting different constituents of a firm (Coleman, 2008). With an original view of the firm the shareholder is the only one recognized by business law in most countries because they are the owners of the companies. In view of this, the firm has a fiduciary duty to maximize their returns and put their needs first. In more recent business models, the institution converts the inputs of investors, employees, and suppliers into forms that are saleable to customers, hence returns back to its shareholders.

This model addresses the needs of investors, employers, suppliers and customers. Pertaining to the scenario above, stakeholder theory argues that the parties involved should include governmental bodies, political groups, trade associations, trade unions, communities, associated corporations, prospective employees and the general public. In some scenarios competitors and prospective clients can be regarded as stakeholders to help improve business efficiency in the market place. Stakeholder theory has become more prominent because many researchers have recognized that the activities of a corporate entity impact on the external environment requiring accountability of the organization to a wider audience than simply its shareholders.

\section{Research Design}

The research adopts the basic research and ex-post facto research design (Adetayo, 2011) using panel data. This is because the study combines time series and cross-sectional data for the sampled banks over a period of five (5) years $(2014-2018)$. The data collected at these different time period were analysed to discover trends over the period. To achieve the objectives set out at the commencement of this work, there is a need to gather data on two variables (Independent and Dependent). Data on Corporate Governance elements (Independent) and data on profitability (performance) of the sampled banks for the period covered $(2014-2018)$.

\section{Source of Data}

The data to be used in this research will be secondary and will be generated from the published annual financial statements of the ten (10) banks under study covering a period of five (5) years (2014 - 2018).

\section{Population, Sample Size and Sample Technique}

The population of this research consists of the twenty-one (21) listed commercial banks, as released by the Central Bank of Nigeria in December, 2018. These banks were so used because they were considered viable and were seen to have the required financial requirements to carry on banking business in Nigeria

From these banks, ten (10) banks will be purposively taken out of the population under consideration based on certain parameters stated in this study. These banks are Zenith bank, Guaranty Trust Bank, First Bank, Access bank, United Bank for Africa, Fidelity Bank, Ecobank, Wema Bank, First City Monument Bank and Diamond Bank. The sampling technique used is the judgemental non-probabilistic sampling technique based on certain parameters. The parameters used in selecting the banks were the indicators of the strength of a bank: its international reckoning, profitability, shareholders's fund, total assets, earnings and customer deposits. This is because only listed banks can be termed public limited liability banks (Plc.) which are also expected to comply fully with the requirements of $\mathrm{CBN}$ code of corporate governance. Also, being listed enabled the researcher to have access to the banks' annual reports used in the course of this research.

\section{Measurement of Variables}

The independent variables of the study are corporate governance, board size, non-executive directors and female directors. These will be measured as follows:

Corporate Governance: A corporate governance disclosure index (CGDI) will then be computed by using the following formula: 


$$
\text { CGDI }=\frac{\text { Total Score of the Individual Company }}{\text { Maximum Possible Score Obtainable by Company }} \times 100
$$

Where the total score of the individual company = the number of issues or condition or requirement under the post-consolidation code of best practices met by each banks, while the maximum possible score obtainable by each company $=$ the total number of issues under the post-consolidation code of best practices (that is 25).

Board Size: This measures the total number of directors, both executives and Non-executives.

Non-Executive Directors: This measures the number of non-executive directors sitting on the board. Female Directors: This measures the number of female directors.

The dependent variable is banks profitability and this will be measured by market price per share (MPS), where market per share (MPS) is the price at which one unit of a company's stock is sold

\section{Data Analysis Methods}

The data for this research will be analysed with respect to each objective of the study. The data analysis techniques to be used are as follows:

Objective 1: With the help of the list of disclosure issues (see appendix), the annual reports of the banks will be examined and a dichotomous procedure of content analysis will follow to score each of the disclosure issue. Each bank will be awarded a score of " 1 " if it appears to have disclosed the concerned issue and " 0 " if otherwise. The score of each bank was totalled to find out the net score of the bank. A corporate governance disclosure index (CGDI) was then computed to ascertain the trend of corporate governance disclosure.

Objective 2: Objective two will be analysed using simple regression analysis

Objective 3: The relationship between the variables will be ascertained using multiple regression analysis.

\section{RESULTS AND DISCUSSION}

Trend Analysis Graph of Corporate Governance Disclosure Index for Zenith Bank for the Period of 2014 - 2018.

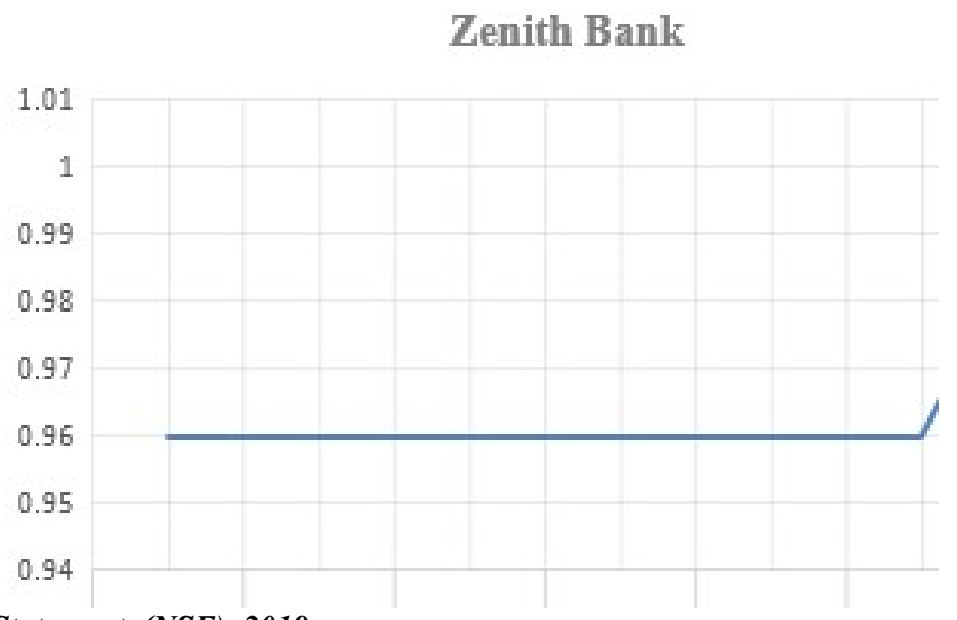

Source: Financial Statement, (NSE). 2019 
Trend Analysis Graph of Corporate Governance Disclosure Index for Guaranty Trust Bank for the Period of 2010 - 2016.

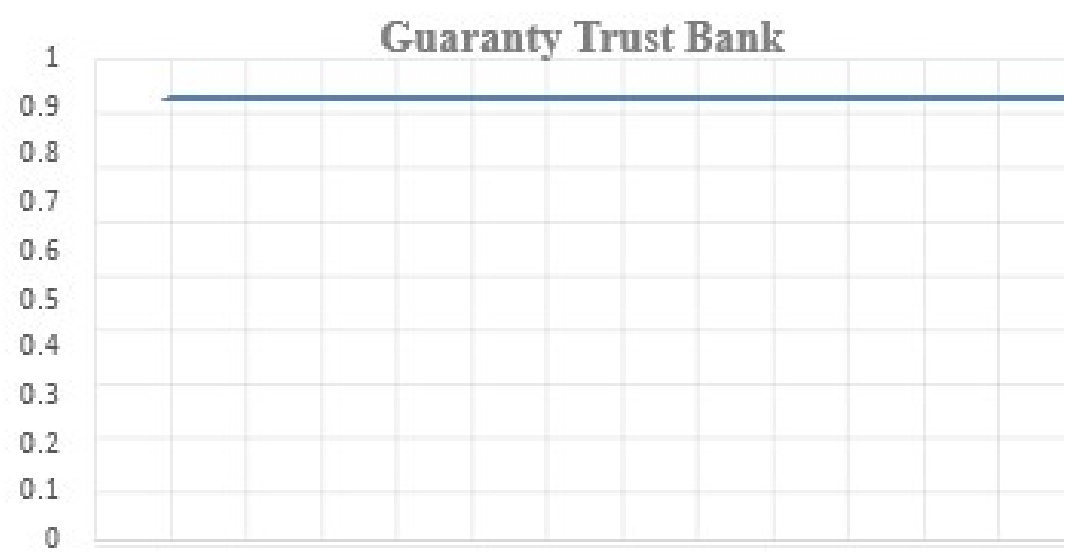

Source: Financial Statement, (NSE).

Trend Analysis of Corporate Governance Disclosure of First Bank for the Period of 2014-2018.

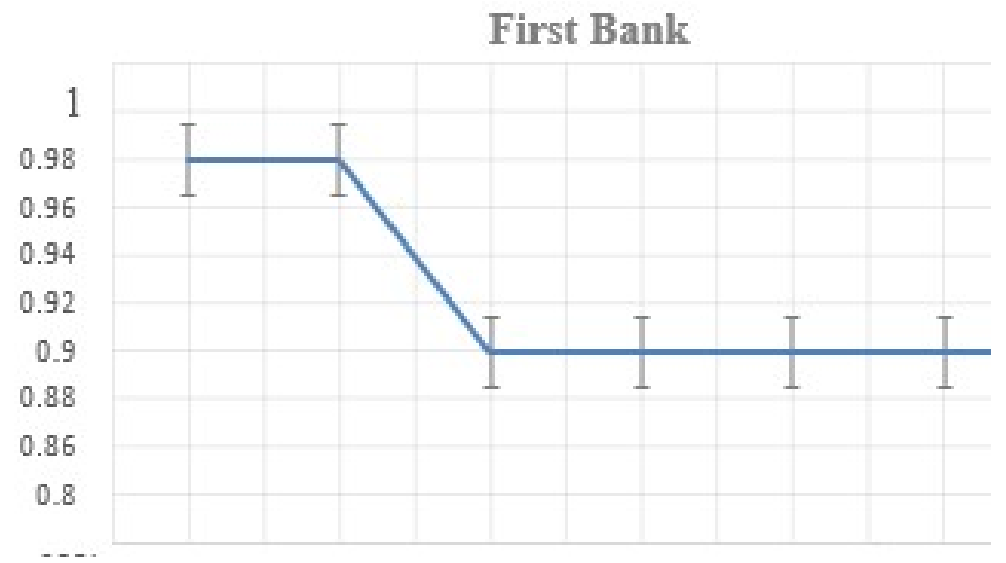

Source: Financial Statement, (NSE). 2019

Trend Analysis of Corporate Governance Disclosure of Access Bank for the Period of 2010-2016.

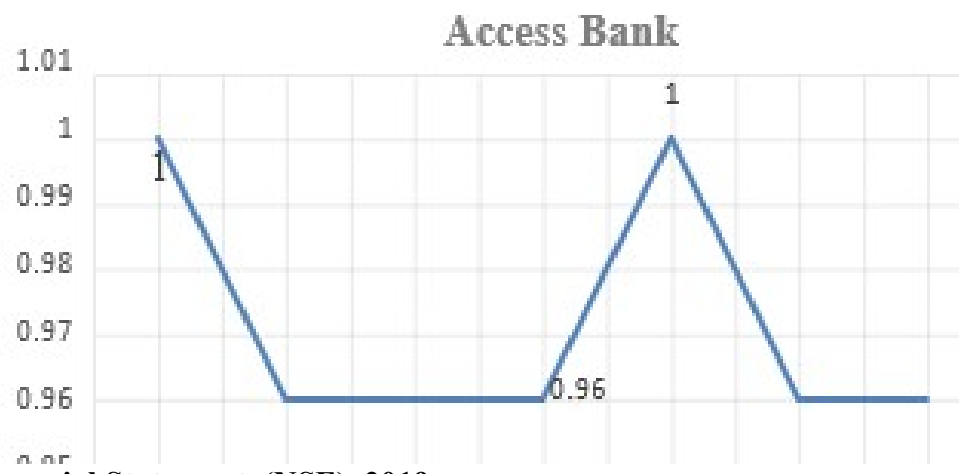

Source: Financial Statement, (NSE). 2019 
Trend Analysis of Corporate Governance Disclosure of United Bank for Africa for the Period of 20102016.

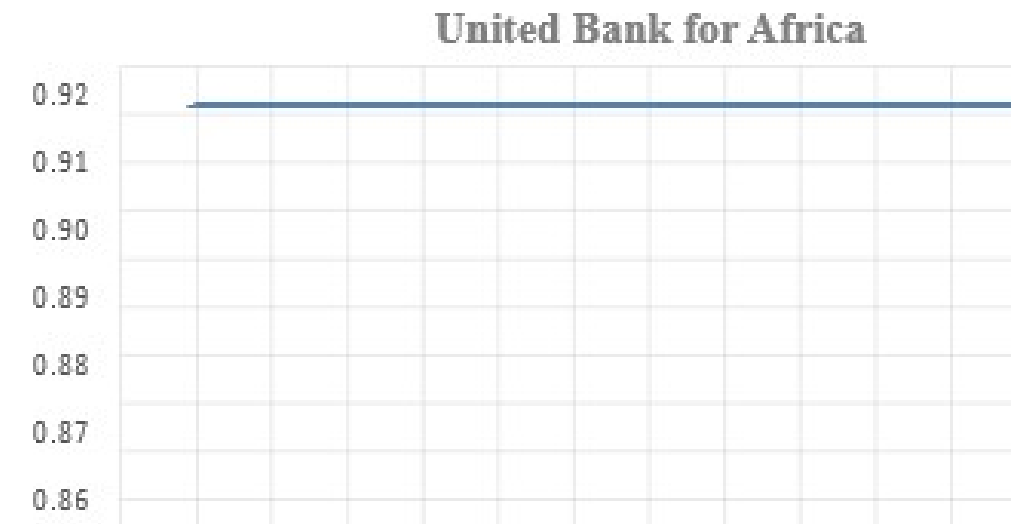

Source: Financial Statement, (NSE). 2019

Trend Analysis of Corporate Governance Disclosure of Fidelity Bank for the Period of 2014-2018.

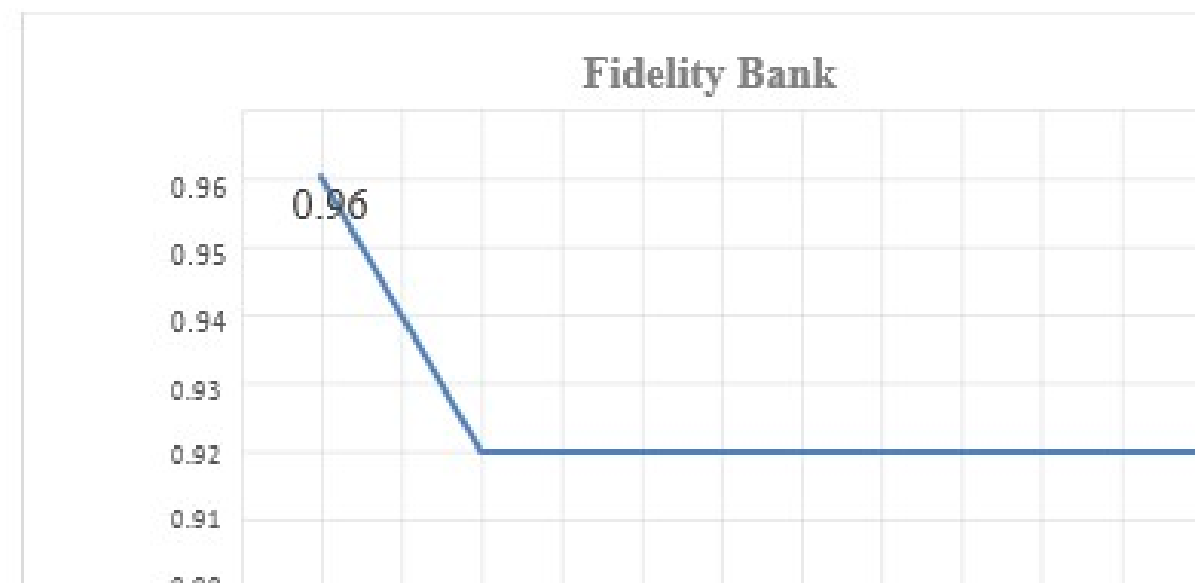

Source: Financial Statement, (NSE). 2019

Trend Analysis of Corporate Governance Disclosure of Ecobank for the Period of 2014-2018.

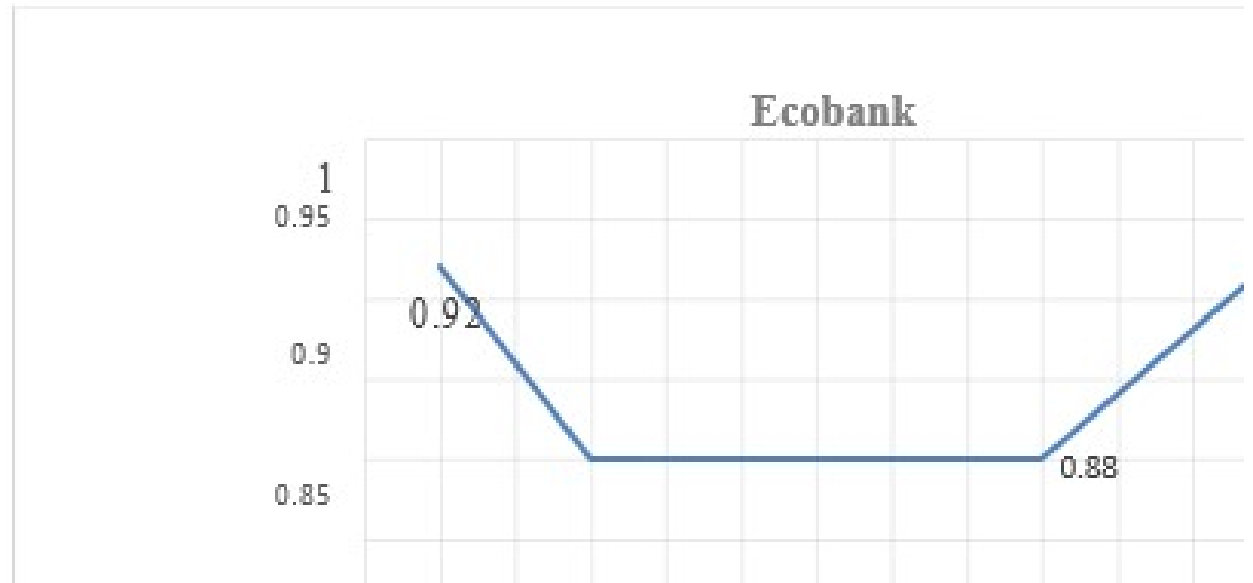

Source: Financial Statement, (NSE). 2019 
Trend Analysis of Corporate Governance Disclosure of Wema Bank for the Period of 2014-2018

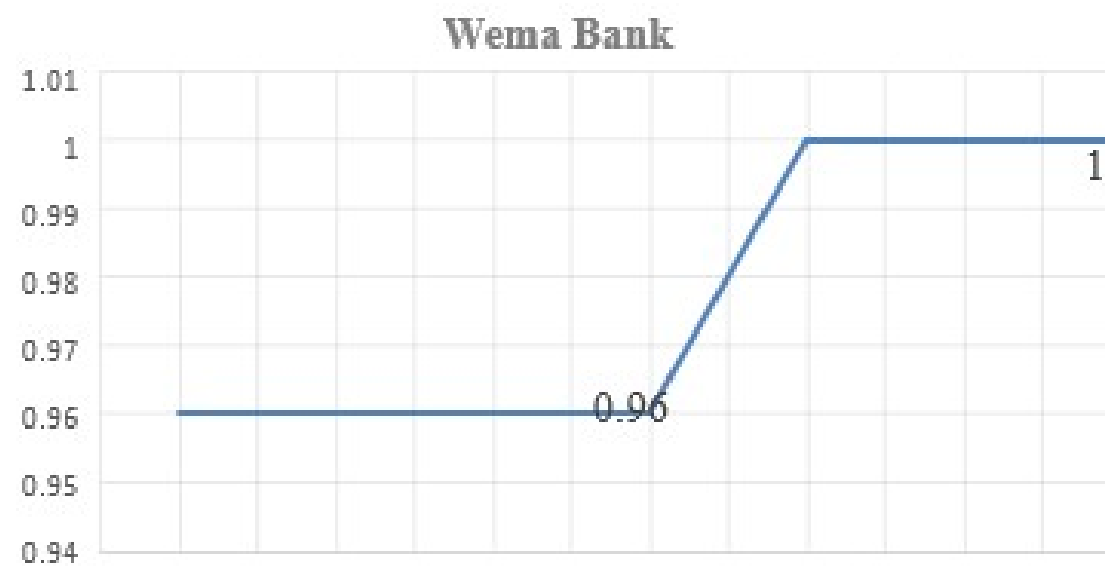

Source: Financial Statement, (NSE). 2019

Trend Analysis of Corporate Governance Disclosure of First City Monument Bank (FCMB) for the Period of 2010-2016.

\section{First City Monument Bank (FCMB)}

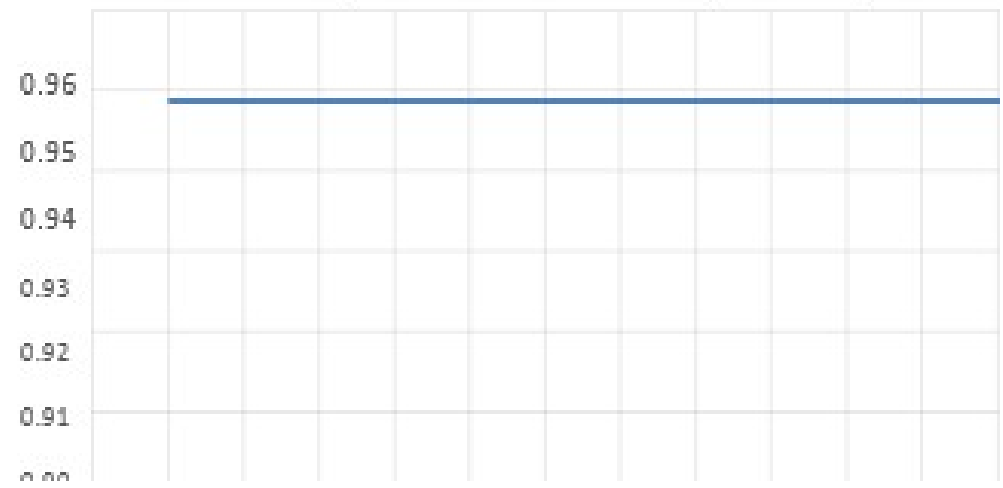

Source: Financial Statement, (NSE). 2019

Trend Analysis of Corporate Governance Disclosure of Diamond Bank for the Period of 20142018.

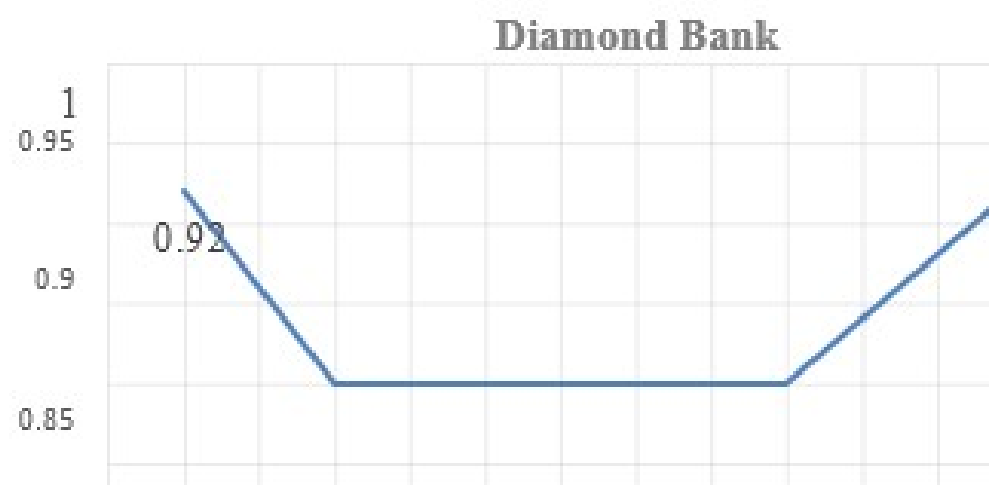

Source: Financial Statement, (NSE). 2019 
Relationship between the level of Corporate Governance Disclosure and the performance of Commercial banks in Nigeria.

Objective two of this study examined the relationship between the level of Corporate Governance Disclosure and the performance of Commercial banks. The researcher used a correlation analysis to examine this relationship. The table showed that there was a weak negative relationship of $2.79 \%$ between corporate governance disclosure index (CGDI) and market price per share (MPS) of Nigerian banks. This negative relationship indicated that the two variables move in opposite direction and moreover, it implied that both variables could explain each other negatively by 0.0279 .

Relationship between Corporate Governance Disclosure Index and Market Price per Share of Nigeria Banks.

\begin{tabular}{|l|l|l|}
\hline VARIABLE & MPS & CGDI \\
\hline MPS & 1.0000 & \\
& $(0.0000)$ & \\
\hline CGDI & -0.0279 & 1.0000 \\
& $(0.0420)$ & $(0.0000)$ \\
\hline
\end{tabular}

Source: Financial Statement, (NSE). 2019

Effect of Corporate Governance characteristics on the Performance of Commercial Banks in Nigeria.

The stock performance being the response variable was captured by Market price per share (MPS) while the explanatory variables included Board Size (BS), Non-Executive director (NED) and Number of Female director (NUM) are the regressors used in achieving this objective. Ordinary least square methods of three models namely fixed effect; random effect and ordinary effect were estimated. Post estimation diagnostic test of Hausman test and redundant fixed effect test were adopted in selecting the most appropriate model to capture the impact of corporate governance characteristics on stock performance of banks. The test indicated that random effect is not an appropriate model and non-normality of the variables will not encourage the use of ordinary effect, therefore, in estimating the parsimonious model of the variable, fixed effect will be an appropriate assumption. $86.78 \%$ of the stock performance of banks was accounted for by the explanatory variables, while after adjusting the co-efficient of determination due to degree of freedom, the percentage of banks 'stock performance fell to $80.77 \%$, this implies that about $80.77 \%$ of the banks stock performance was accounted for by the explanatory variables. The F-statistics of 14.4464 , with the p-value $<0.05$ so that the explanatory variables are jointly different from zero and Durbin-Watson statistics of 1.986465 reported the likelihood of no autocorrelation. Based on the result, only one of the three explanatory variables number of executive director (NED) $(\boldsymbol{\beta}=-0.290836, \mathrm{t}=-0.570188$ and $\mathrm{p}$-value $=0.0425)$ was significant at $95 \%$ level of confidence.

From this result, the number of executive director (NED) was negatively and significantly related to banks' stock performance at $5 \%$ level, the following statistics were estimated of NED using Fixed Effect Method, $(\boldsymbol{\beta}=$ $0.290836, \mathrm{t}=-0.570188$ and $\mathrm{p}$-value $=0.0425)$ This signified that banks' stock performance will decrease by $29.08 \%$ given a $100 \%$ increase in NED of banks. Based on this result, it is advisable for Nigerian banks to pay attention to the structure of its non-executive directors as it has a significant negative effect on the market price per share of banks. This negative contribution between NED and banks ${ }^{\text {ee }}$ stock performance negate our aprior expectation.

Correlation Matrix

\begin{tabular}{|l|l|l|l|l|}
\hline VARIABLE & MPS & BS & NED & NUM \\
\hline MPS & 1.0000 & & & \\
& $(0.0000)$ & & & \\
\hline BS & & & & \\
& -0.13798 & 1.0000 & & \\
\hline NED & $(0.9550)$ & $(0.0000)$ & & \\
& -0.3538 & 0.570902 & 1.0000 & \\
\hline NUM & $(0.0452)$ & $(0.0172)$ & $(0.0000)$ & \\
& 0.023136 & 0.252969 & -0.03672 & 1.0000 \\
& $(0.1586)$ & $(0.1389)$ & $(0.25191)$ & $(0.0000)$ \\
\hline
\end{tabular}

Source: Financial Statement, (NSE). 2019 


\section{Multiple Regression Analysis}

\begin{tabular}{|c|c|c|c|c|}
\hline & & $\begin{array}{l}\text { Pooled } \\
\text { Effect }\end{array}$ & $\begin{array}{l}\text { Fixed } \\
\text { Effect }\end{array}$ & $\begin{array}{r}\text { F } \\
]\end{array}$ \\
\hline & coff. & 0275916 & 0.437792 & $0:$ \\
\hline \multirow[t]{3}{*}{$\mathrm{BS}$} & $t-s t a t$ & 0.322224 & 0.946382 & 1. \\
\hline & p-value & 0.7488 & 0.3508 & \\
\hline & coff. & -1.53293 & -0.290836 & \\
\hline \multirow[t]{3}{*}{ NED } & t-stat & -2.2191 & -0.570188 & \\
\hline & p-value & 0.0326 & 0.0425 & \\
\hline & coff. & 0.042058 & -0.09748 & \\
\hline \multirow[t]{3}{*}{ NUM } & t-stat: & 0.169825 & -0.56165 & \\
\hline & p-value & 0.8659 & 0.5781 & \\
\hline & coff. & 4.575552 & 1.606577 & 1 \\
\hline \multirow[t]{2}{*}{$\mathrm{c}$} & t-stat & 2.723483 & 1.383424 & \\
\hline & p-value & 0.0092 & 0.1758 & \\
\hline R-Squared & & 0.13181 & 0.867839 & $0.0:$ \\
\hline Adj.R-sq & & 0.07393 & 0.807766 & \\
\hline F-Stat & & 2.277316 & 14.4464 & 43 \\
\hline Prob (F-stat) & & 0.0292477 & 0.0000 & 0.7 : \\
\hline \multicolumn{2}{|c|}{ Durbin-Watson Stat } & 1.952655 & 1.986465 & 1.7 \\
\hline
\end{tabular}

\section{CONCLUSION AND RECOMMENDATIONS}

Based on the findings of this study, it showed that only the number of non-executive directors had a negative effect on the market price per share of the banks under study. The findings of this study revealed that importance should be placed on the board characteristics of banks especially the on the number of non-executive directors which was significant to the market price per share. It showed that banks 'stock performance will decrease by $29.08 \%$ given a $100 \%$ increase in number of non-executive directors (NED) of banks.

The study concluded that there is uniformity in the disclosure of corporate governance practices made by banks in Nigeria. Findings also showed that most banks just stated that the right of shareholders are protected especially the right to vote at the annual general meeting but did not state in details the other rights of shareholders Furthermore, the study concludes that a negative relationship exists between the level of corporate governance disclosure and the stock performance of deposit money banks in Nigeria. Based on the findings of this research, the following recommendations are made which will be useful to internal and external 
stakeholders.

Firstly, efforts should be made to improve corporate governance focus on the stock performance of deposit money banks since the stock performance is a measure of the wealth of shareholders.

Secondly, the Central bank of Nigeria and other relevant authorities should also try to ensure that steps are taken for mandatory and absolute compliance with the code of corporate governance. Also, an effective legal framework should be developed that specifies the rights and obligations of a bank, its directors, shareholders, specific disclosure requirements and provide for effective enforcement of the law. Authority may place higher emphasis on certain aspect of governance if they are considered to be a basic component or prerequisite to implementing others and thus should be given more weight.

Finally, there is the need to set up a unified corporate body saddled with the responsibility of collecting and collating corporate governance related data and constructing the relevant indices to facilitate corporate governance research in Nigeria as the study stated that corporate governance disclosure has a positive relationship with the market price per share of deposit money banks in Nigeria.

\section{References}

Adetayo, E. D. (2011). Guide to Business Research and Thesis Writing. Ibadan: Rasmed publications limited Ibadan, Nigeria.

Cadbury, A. (1992). Report of the committee on the Financial Aspects of Corporate Governance. London: Gee Publishing.

Clarke, T. (2004). The stakeholder corporation: A busines philosophy for the Information age. In Theories of Corporate Governance the Philosophical Foundations of Corporate Governance (189-202). London: Pout Ledge.

Hermalin, K. F. (2005). Additions to corporate boards: The effect of gender. Journal of Corporate Finance, 11, $85-90$.

Meckling, M. J. (1976). Theory of the Firm: Managerial Behaviour, Agency Costs and Ownership Structure. In L. Putterman, The Economic Nature of the Firm. Cambridge University Press. 